\title{
Učinkovitost računalniškega kognitivnega treninga $v$ domovih starejših občanov
}

\author{
Uroš Marušič $\check{c}^{1,2 *}$ Zdenka Milič Žepič ${ }^{3}$ in Vojko Kavčič $\check{c}^{3,4}$ \\ ${ }^{1} Z$ Znanstveno-raziskovalno središče Koper \\ ${ }^{2}$ Alma Mater Europaea - Evropski center Maribor \\ ${ }^{3}$ Mednarodni inštitut za aplikativno gerontologijo, Ljubljana \\ ${ }^{4}$ Institute of Gerontology, Wayne State University, Detroit, Michigan, ZDA
}

\begin{abstract}
Povzetek: Ohranjanje in krepitev fizičnega in kognitivnega zdravja je pri starejših osebah izziv, še posebej pri tistih, ki so podvržene pospešenim starostnim ali nevrodegenerativnim spremembam. Obstoječe nefarmakološke intervencije lahko stabilizirajo ali upočasnijo kognitivni upad, vendar se učinkovite preventivne tretmaje, ki bi zakasnili pojavnost simptomov, še raziskuje. Eden izmed nefarmakoloških tretmajev je kognitivni trening. Namen naše raziskave je bil oceniti izvedljivost in učinkovitost kognitivnega treninga $\mathrm{z}$ nalogo prostorske navigacije pri stanovalcih domov starejših občanov. Enaintrideset stanovalcev (povprečna starost 81,6 leta, razpon 69-94 let; povprečna ocena MoCA 22,8 točke, razpon 17-27; 7 moških) je bilo naključno razporejenih v kontrolno skupino ali intervencijsko skupino. Slednja je bila vključena v dvomesečni kognitivni trening (2-krat tedensko; skupaj 16 treningov), v katerem so udeleženci vadili učenje virtualnega labirinta. Vsi udeleženci raziskave so bili merjeni pred in po intervenciji na nevropsihološki ocenjevalni bateriji testov. Udeleženci kontrolne skupine niso prejeli nobene posebne obravnave in so tako sodelovali le na »pred in po« meritvah. Pomembne izboljšave so bile ugotovljene le pri Reyjevem testu slušno-besednega učenja (AVLT), kjer so udeleženci v intervencijski skupini značilno izboljšali svoj rezultat v primerjavi s kontrolno skupino. Kljub omejeni učinkovitosti kognitivnega treninga je bila naša intervencija izvedljiva in pozitivno sprejeta s strani večine udeležencev. Nadaljnje raziskave bi morale ovrednotiti dolgoročne učinke kognitivnega treninga na druge funkcionalne sposobnosti in aktivnosti vsakodnevnega življenja. Na splošno naša raziskava ponuja empirične dokaze, da je kognitivni trening sprejemljiv za stanovalce domov za starejše občane, in kar je najpomembneje, da lahko izboljša mnemonične kognitivne sposobnosti.
\end{abstract}

Ključne besede: staranje, kognitivni trening, naloga prostorske navigacije, virtualni labirint, transfer, domovi za starejše občane

\section{Effectiveness of computerized cognitive training in nursing homes}

\author{
Uroš Marušič ${ }^{1,2^{*}}$, Zdenka Milič Žepič ${ }^{3}$ in Vojko Kavčičč ${ }^{3,4}$ \\ ${ }^{1}$ Science and Research Centre Koper, Slovenia \\ ${ }^{2}$ Alma Mater Europaea - European Centre Maribor, Slovenia \\ ${ }^{3}$ International Institute of Applied Gerontology, Ljubljana, Slovenia \\ ${ }^{4}$ Institute of Gerontology, Wayne State University, Detroit, Michigan, USA
}

\begin{abstract}
Maintaining and improving physical and cognitive health is becoming a challenging task, especially for older people who are exposed to accelerated age- or neurodegenerative-related decline. Existing non-pharmacological interventions may stabilize or slow down cognitive decline, but effective preventive treatments that would delay the symptom onset are currently being explored. One of such non-pharmacological treatments is cognitive training, which has gained in popularity over the last two decades. The aim of our research was to evaluate the feasibility and effectiveness of cognitive training with spatial navigation task in nursing home residents. Thirty-one nursing home residents (mean age $=81.6$ years, range 69-94 years; mean MoCA score $=22.8$, range 17-27; 7 male) were randomly assigned to control or intervention group, where they underwent a 2-month cognitive training (two-times weekly; altogether 16 sessions) with virtual maze navigation. Participants were measured pre- and post-intervention on neuropsychological assessment battery, while the control group received no specific treatment and performed pre- and postmeasurements only. The only significant improvements were found on Rey Auditory Verbal Learning Test (AVLT) where participants in the intervention group significantly improved as compared to their control counterparts. Despite limited generalization of cognitive training, our intervention was feasible and positively perceived by the majority of nursing home residents. Future studies should evaluate long-term effects and generalization to other functional capabilities as well as activities of daily living. Overall, our study provides empirical evidence that cognitive training is accepted by nursing home residents, and most importantly, can improve mnemonic cognitive abilities.
\end{abstract}

Keywords: aging, cognitive training, spatial navigation task, virtual maze, transfer of learning, nursing homes

*Naslov/Address: dr. Uroš Marušič, Inštitut za kineziološke raziskave, Znanstveno-raziskovalno središče Koper, Garibaldijeva 1, 6000 Koper, e-mail: umarusic@outlook.com

Članek je licenciran pod pogoji Creative Commons Attribution 4.0 International licence. (CC-BY licenca).

The article is licensed under a Creative Commons Attribution 4.0 International License (CC-BY license). 
Staranje neizbežno privede do sprememb v kognitivnem funkcioniranju, predvsem do upada kognitivnih sposobnosti. Prav upad kognitivnih sposobnosti postaja eden najbolj perečih vidikov staranja (Deary idr., 2009), ki lahko vodi v upad kvalitete življenja in izgubo avtonomnosti (Blazer idr., 2015). Ko kognitivni upad v vsakdanjem delovanju postane tako moteč, da lahko ogroža varnost starostnika, začnemo razmišljati o namestitvi v dom za starejše občane (DSO). Za namestitev v dom se lahko starostniki odločijo že pred resnimi upadi, tako da v DSO-jih prebivajo tudi posamezniki brez kognitivnega primanjkljaja.

Preselitev starejše osebe v institucionalno varstvo (DSO) V skladu s slovenskimi predpisi starejšemu posamezniku omogoča kvalitetno življenje na način, »da nadomešča ali dopolnjuje funkcijo doma ali lastne družine« (Zakon o socialnem varstvu, 2007, čl. 16). Po tem zakonu imamo v slovenskih DSO aktivnosti in poklice (socialne delavce, delovne terapevte), ki naj bi med drugim skrbeli tudi za ohranjanje kognitivnih sposobnosti stanovalcev. Tako se $\mathrm{v}$ okviru delovne terapije $\mathrm{v}$ slovenskih DSO izvajajo dejavnosti, kot so npr. reševanje križank in ugank, igranje šaha, gospodinjske aktivnosti in druge splošne vaje in naloge, ki pa so bolj usmerjene $\mathrm{v}$ ohranjanje spretnosti. Nekatere raziskave so pokazale, da rutinske aktivnosti v DSO, kot je gledanje TV (kar se v DSO pogosto dogaja), niso kognitivno stimulirajoče (Wang idr., 2006). Lindstrom idr. (2005) celo menijo, da je gledanje TV lahko dejavnik tveganja za razvoj demence.

$\mathrm{S}$ preselitvijo $\mathrm{v}$ DSO je povezana tudi sprememba okolja, ki zahteva reorganizacijo v načinu življenja. Imperl (2012) opozarja, da je okolje institucije posebno oziroma »neobičajno okolje«, kjer posameznik lahko doživlja občutek izgubljanja identitete. Zato se postavlja vprašanje, ali v instituciji posameznik še vedno sam odloča o svojem življenju. Pri udeležencih iz DSO se torej poleg vprašanja na splošno znižanih kognitivnih sposobnostih pojavi še vprašanje motiviranosti za udeležbo v kognitivnem treningu (KT) ali računalniškem kognitivnem treningu (RKT). Skratka, aktivnosti v okviru delovne terapije se razlikujejo od KT, ki je specifično usmerjen v vzdrževanje in izboljšanje kognitivnih sposobnosti, ne pa zgolj $\mathrm{v}$ razvoj določenih spretnosti (Bahar-Fuchs idr., 2019; Mapelli idr., 2013).

Imperativ vsake družbe je, da omogoča in pomaga starostnikom, da čim dlje ohranjajo svoje kognitivne sposobnosti. Med pogosto omenjene preventivne strategije za preprečitev s staranjem povezanih kognitivnih upadov poleg primerne gibalno/športne ter socialne aktivnosti in diete sodi tudi kognitivna aktivnost. Več metaanaliz poroča o različnih kognitivnih intervencijah (predvsem KT in bolj specifično RKT) in navaja empirične dokaze o njihovi učinkovitosti pri ohranjanju ali celo izboljšanju kognitivnih sposobnosti pri starejših brez kognitivnega primanjkljaja (Lampit idr., 2014; Mewborn idr., 2017), kakor tudi pri tistih, ki že kažejo blag kognitivni upad oziroma blago kognitivno motnjo (npr., Bahar-Fuchs idr., 2019).

KT je proces učenja strategij za izboljšanje kognitivnih funkcij, ki se najpogosteje izvaja kot individualizirana vadba ali vadba v manjših skupinah. Vključuje vodene vaje standardnih nalog na področjih treninga spomina, pozornosti ali reševanja zastavljenih problemov (Marusic in Grosprêtre, 2018). Tovrstno usposabljanje se izvaja $\mathrm{z}$ namenom izboljšanja ali vsaj ohranjanja kognitivnih funkcij posameznika. Za dosego optimalnih rezultatov je pomembna stopnja težavnosti, ki je prilagojena sposobnosti vadečega posameznika in/ali skupine. Z razvojem informacijsko-komunikacijske tehnologije je v zadnjih letih narasla popularnost RKT, ki se kaže tudi v številu znanstvenih objav (Harvey idr., 2018).

Raziskav, ki bi poročale o KT in RKT pri starejših udeležencih brez kognitivnega primanjkljaja iz DSO, je relativno malo, kajti večina RKT v DSO je potekala na stanovalcih $\mathrm{z}$ blago kognitivno motnjo oziroma $\mathrm{Z}$ Alzheimerjevo boleznijo (glej pregled v Folkerts idr., 2017; Wöhl idr., 2018). Raziskave, ki so jih vključili v metaanalizo Folkerts idr. (2017), so bile dokaj raznolike, ne samo glede poročanja o pozitivnih ali negativnih rezultatih, ampak tudi glede učinkov na kognitivno funkcioniranje, na vsakdanjo manifestacijo simptomov in učinkov na kvaliteto življenja. Raziskave so se tudi razlikovale glede različnih uporabljenih intervencij, od reminiscence do kognitivnega treninga, kognitivne rehabilitacije, kognitivne stimulacije, realitetne orientacije in do kombiniranih, multimodalnih intervencij. Kognitivni status udeležencev oziroma nivo dementnosti, izmerjen s kratkim preizkusom spoznavnih sposobnosti, $\mathrm{v}$ teh raziskavah tudi dokaj variira (od 7 pa do 24 točk od skupno 30 možnih). Primerjava različnih intervencij je pokazala, da je bil v primerjavi z ostalimi intervencijami najbolj učinkovit KT. Na osnovi rezultatov metaanalize 27 člankov o kognitivnih intervencijah v DSO je A.-K. Folkerts s sodelavci (2017) zaključila, da so kognitivne intervencije pri stanovalcih z demenco v tem okolju izvedljive. A. -K. Folkerts idr. (2017) tudi menijo, da je potrebnih še več raziskav na tem področju, da bi ugotovili, katere izmed intervencij so najbolj primerne tako za stanovalce brez kognitivnega primanjkljaja kot tudi za dementne bolnike, ter katere izhodne mere so potrebne za bolj zanesljivo in natančno merjenje na vedenjski in psihološki ravni ter na področju kvalitete življenja.

Glede na stanje stanovalcev v DSO, ki so običajno kognitivno bolj prizadeti kot še samostojno živeči starejši (Folkerts idr., 2017), je pri njih izvedljivost RKT vprašljiva, saj predstavlja uporaba računalnika veliko kognitivno zahtevo, ki lahko vpliva na izvedbo RKT. Poleg tega je generacija, ki trenutno živi v DSO, tudi manj računalniško pismena. Torej je razumljivo, da so raziskave o RKT v DSO redke. Edina, ki nam jo je uspelo odkriti, je raziskava Zhuanga idr. (2013), ki poroča, da RKT lahko izboljša kognitivno funkcioniranje pri stanovalcih $\mathrm{v}$ DSO, in to predvsem pri tistih, ki so manj kognitivno prizadeti.

Namen naše raziskave je bil predvsem raziskati izvedljivost RKT v DSO ter učinkovitost takšnega treninga, ki obsega vaje za krepitev spomina, pozornosti in hitrosti procesiranja informacij pri starejših. RKT smo izvedli z uporabo naloge virtualnega labirinta, ki za uspešno učenje labirinta zahteva predvsem angažiranje pozornosti ter spominskih in izvršilnih sposobnosti (Moffat idr., 1998). Na podlagi predhodnih ugotovitev smo predvidevali, da bo RKT v DSO izvedljiv in da bo pokazal izboljšanje kognitivnih sposobnosti. 


\section{Metoda}

\section{Udeleženci}

$\mathrm{V}$ raziskavo je bilo vključenih 31 prebivalcev domov za starejše, starih med 69 in 94 let $(M=81,6, S D=6,8)$, med katerimi je bilo sedem moških. Vsi udeleženci so bili desnoročni in so na raziskavo (meritve in intervencijo) prišli sami ali v spremstvu terapevta. Pred pričetkom raziskave so vodstva DSO odobrila izvajanje RKT. Vsi udeleženci so bili seznanjeni s potekom raziskave in so podpisali izjavo o zavestni in svobodni privolitvi za sodelovanje. Udeleženci so bili naključno razdeljeni $\mathrm{v}$ dve skupini, intervencijsko in kontrolno, ter so opravili evalvacijo kognitivnih sposobnosti $\mathrm{v}$ dveh meritvenih obdobjih (pred in po 8-tedenskem obdobju izvajanja intervencije). Tabela 1 prikazuje začetne vrednosti dosežkov intervencijske in kontrolne skupine.

\section{Pripomočki}

Kognitivni testi. Začetno testiranje je bilo opravljeno z Montrealsko lestvico spoznavnih sposobnosti - MoCA (Nasreddine idr., 2005), kjer smo za končni rezultat vzeli skupni seštevek vseh podsklopov lestvice (vidno-prostorske/ izvršilne sposobnosti, poimenovanje, spomin, pozornost, jezik, abstrakcija, odloženi priklic in orientacija). MoCA je kratko kognitivno presejalno orodje $\mathrm{z}$ visoko občutljivostjo in specifičnostjo za odkrivanje blage kognitivne motnje (Nasreddine idr., 2005). Višje število točk pomeni boljši rezultat.

Test slušno-besednega učenja (Auditory-Verbal Learning Test - AVLT) smo uporabili za merjenje besednega spomina, odloženega priklica, prepoznavanja, proaktivne in retroaktivne interference (Van Der Elst idr., 2005). Test je sestavljen iz dveh seznamov po 15 besed. V prvem delu testa testirancu preberemo prvi seznam besed (seznam A), pri čemer beremo eno besedo na sekundo. $V$ petih zaporednih poskusih uporabimo prvi seznam, kjer rezultat podaja oceno takojšnjega priklica/spomina. Pri šestem poskusu uporabimo drugi seznam (seznam B), ki služi kot moteče orodje (AVLT-B), saj $\mathrm{v}$ sedmem poskusu brez predhodnega prebiranja seznama preverjamo sposobnost priklica besed iz prvega seznama, pri čemer hkrati dobimo oceno posameznikove dovzetnosti za moteče dejavnike. Odloženi priklic (OP) informacij sledi kot osmi poskus po tridesetih minutah, kjer brez prebiranja besed prosimo udeleženca, naj pove čim več besed s prvega seznama (AVLT-OP); nato pri devetem poskusu prosimo udeleženca, da na delovnem listu obkroži tiste besede, ki so se pojavljale na prvem seznamu - naloga prepoznave (AVLT-PRE). Zadnja dva poskusa preverjata sposobnost zadrževanja informacij $\mathrm{v}$ spominu. Vsako pravilno besedo smo točkovali z 1 točko, pri vsakem poskusu je bilo možno dobiti od 0 do 15 točk. Za potrebe naše raziskave smo za rezultate uporabili povprečen dosežek prvih petih poskusov učenja (AVLT-U), dosežek na AVLT-B, AVLT-OP ter AVLT-PRE. Višje število točk na AVLT testih pomeni boljši rezultat.

S testom verbalne fluentnosti (Barry idr., 2008) smo izmerili posameznikove verbalne sposobnosti in spomin. Test vključuje merjenje števila priklicanih besed kot odgovor na neko črko ali določeno kategorijo. Za neodvisno spremenljivko smo uporabili povprečje odgovorov fonetične fluentnosti na črke $\mathrm{F}, \mathrm{A}$ in $\mathrm{S}$ ( Vflue $_{\text {fon }}$ ), semantične fluentnosti kategorije živali $\left(\right.$ Vflue $\left._{\text {sem }}\right)$ in izmenične fluentnosti med kategorijo sadja in pohištva ( Vflue $_{\text {izm }}$ ). Višje število točk na testiranju Vflue pomeni boljši rezultat.

Za test povezovanja (Trail Making Test - TMT) smo uporabili različico D-KEFS TMT, ki je sestavljena iz petih podsklopov, kjer merimo čas, potreben za dokončanje posameznega podsklopa. Podsklop TMT1 meri vidni pregled, TMT2 številčno zaporedje, TMT3 črkovno zaporedje, TMT4 preklapljanje med številkami in črkami in TMT5 hitrost gibanja (Delis idr., 2004). Nižja številka na TMT testiranju pomeni krajši čas reševanja in posledično boljši rezultat.

Test neposrednega pomnjenja zaporedja števil (Wechsler, 1997) je bil sestavljen iz dveh podsklopov: a) pomnjenje števil naprej $\left(\mathrm{KSP}_{\text {nap }}\right)$, ki meri kratkoročni spomin in pozornost, in b) pomnjenje števil nazaj $\left(\mathrm{DS}_{\mathrm{naz}}\right)$, ki meri delovni spomin. $\mathrm{V}$ prvem podsklopu mora posameznik priklicati/ponoviti sekvenco števil v enakem vrstnem redu, kot so števila prvotno podana, medtem ko posameznik $\mathrm{v}$ drugem delu testiranja ponovi podane številke $\mathrm{v}$ obratnem vrstnem redu. Rezultat predstavlja doseženo kategorijo, pri čemer kategorija 1 predstavlja dve števili in kategorija 8 devet števil. Višje število točk na WMS testiranju pomeni boljši rezultat.

\section{Tabela 1}

Demografski podatki in dosežki na Montrealski lestvici spoznavnih sposobnosti (MoCA) pri udeležencih intervencijske in kontrolne skupine

\begin{tabular}{lccc}
\hline Spremenljivke & Intervencijska skupina & Kontrolna skupina & $\begin{array}{c}p \text { vrednost } t \text {-testa razlike med } \\
\text { skupinama }\end{array}$ \\
\hline$N$ & 16 & 15 & 0.266 \\
Starost (leta) & $80.1 \pm 6.8$ & $83.2 \pm 6.8$ & 0.750 \\
Ženski spol $(n)$ & $4 / 16$ & $3 / 15$ & 0.500 \\
Izobrazba (leta) & $11.4 \pm 2.96$ & $11.86 \pm 1.77$ & \\
Rezultat MoCA $(0-30)$ & $23.0 \pm 3.1$ & $22.5 \pm 2.7$ & $3 / 15$ \\
Padec v zadnjem letu $(f)$ & $3 / 16$ & & \\
\hline
\end{tabular}




\section{Slika 1}

Križišče v virtualnem labirintu programskega orodja Maze Training (Brain Powered Games)

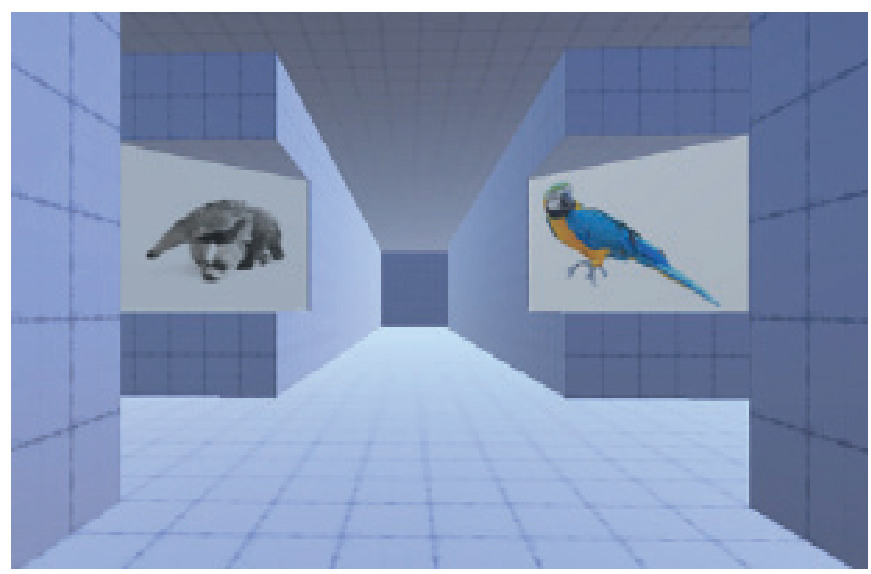

S testom kodiranja ali zamenjave števil s simboli (Digit symbol substitution test - DSST; Wechsler, 1997) merimo psihomotorične sposobnosti. Pri testu DSST ima posameznik nalogo, da pod vsako zapisano številko vstavi pravilen simbol, pri čemer so simboli za različne številke stalno prikazani v zgornjem delu testa. Rezultat testa predstavlja število pravilno zapisanih simbolov v 90 sekundah. Višje število točk na testu DSST pomeni boljši rezultat.

Kognitivni trening. Za RKT smo uporabili programsko opremo, ki je bila razvita v laboratoriju Michigan State Brain Games for Entertainment and Learning (GEL) Lab (direktor dr. Brian Winn) na podlagi predhodno uporabljene različice Unreal Tournament 2003 in programske opreme Editor 3.0 (Epic Games, Inc; Marusic, Giordani idr., 2018; Marusic idr., 2015). Programska oprema omogoča virtualno premikanje znotraj labirintov različnih zahtevnosti z možnostjo izbire poti naravnost, desno ali levo. Naloga udeleženca je, da čim hitreje in natančneje (s čim manjšim številom napak) najde izhod/zaključek labirinta, ki je označen s trofejo. Na vsakem izmed križišč sta udeležencu na voljo dve sliki živali, ki lahko služita kot orientacija v virtualnem prostoru (slika 1). Da bi zagotovili zadostno prilagajanje na virtualni labirint, so vsi udeleženci pričeli RKT z enokrižiščnim labirintom. Na višjo stopnjo (virtualni labirint z več križišči) lahko udeleženec napreduje potem, ko uspešno zaključi labirint dvakrat zaporedoma brez napak. Kot napaka se šteje navigacija v »slepo ulico«, po kateri se mora udeleženec vrniti v zadnje križišče in izbrati drugo možnost (od treh). Hitrost premikanja v virtualnem labirintu je konstantna, smer premikanja pa udeleženci kontrolirajo s puščicami na računalniški tipkovnici (naprej, nazaj, levo in desno).

$\mathrm{V}$ povezavi $\mathrm{z}$ izvajanjem RKT ni bilo poročanih neželenih dogodkov oziroma zapletov. Uporaba računalnika in programske opreme za učenje osnovne navigacije znotraj virtualnega prostora je zahtevala prisotnost več asistentov, ki so udeležence usmerjali in motivirali k aktivnemu izvajanju kognitivnega treninga. Zaradi predhodnega nepoznavanja računalniškega okolja in nezainteresiranosti so štirje udeleženci pred zaključkom raziskave prenehali sodelovati, pet drugih pa raziskave ni zaključilo zaradi zdravstvenih težav, ki niso bile povezane $\mathrm{z}$ izvajanjem intervencije kognitivnega

\section{Slika 2}

Rezultat na testu AVLT-U pred in po dvomesečnem RKT za intervencijsko in kontrolno skupino

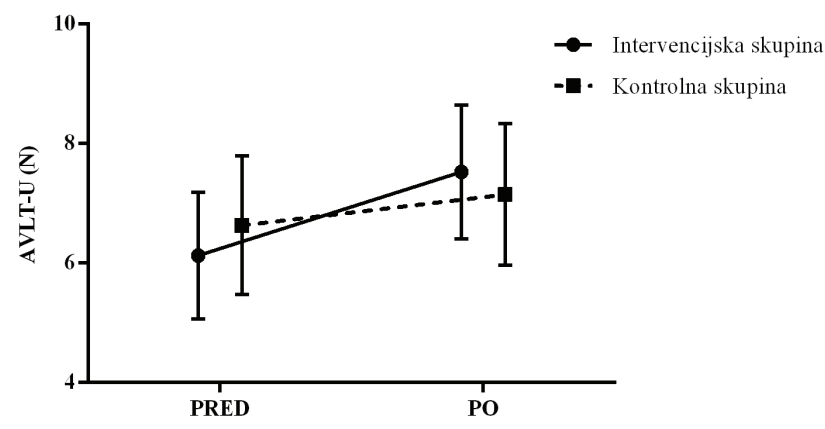

Opomba: Višje vrednosti predstavljajo boljši rezultat. Na grafu je poleg aritmetične sredine prikazan 95-odstotni interval zaupanja.

treninga in/ali meritev raziskave. Dodatna opažanja raziskovalcev kažejo na potrebo po poenostavitvi postopka izvajanja kognitivnega treninga, vključno s poenostavitvijo začetnih korakov, ki bi omogočili uporabniku hitrejšo in samostojno uporabniško izkušnjo.

\section{Analiza podatkov}

Podatke smo obdelali $\mathrm{s}$ programskim orodjem IBM SPSS Statistics (verzija 26.0). Normalnost porazdelitve je bila preverjena s Shapiro-Wilkovim testom ter grafično prek histogramov. Za preverjanje učinkovitosti RKT smo uporabili analizo variance za ponovljene meritve ter njen neparametrični ekvivalent (Friedmanovo ANOVO). Odločitve smo sprejemali pri $p<0,05$.

\section{Rezultati}

Rezultati kratkega preizkusa z Montrealsko lestvico spoznavnih sposobnosti (MoCA) nakazujejo, da je večina udeležencev kazala blag kognitivni upad (tabela 1). Razpon MoCA točk je segal od 17 do 27. Le pet prebivalcev DSO iz intervencijske in štirje iz kontrolne skupine so dosegli rezultat $\mathrm{MoCA} \geq 26$.

Rezultati RKT so pokazali, da je 16 udeležencev uspešno zaključilo dvomesečni RKT. Čas treninga se je med udeleženci razlikoval in dosegel povprečno vrednost $650,1 \mathrm{~min}$ $(S D=178,8) \mathrm{v}$ povprečno 14,4 treninga (minimalno 9 , maksimalno 16 srečanj). Devet udeležencev je bilo iz raziskave predhodno izključenih, saj niso zaključili minimalnega zahtevanega števila treningov, ki je bilo določeno na 8 (od 16). Med izključenimi udeleženci je ena oseba zaključila 4, dve osebi 2, pet oseb 1 in ena oseba nobenega treninga. Kot razlog neudeležbe ali predčasnega prenehanja RKT so udeleženci navajali zdravstvene razloge in pomanjkanje interesa za RKT.

Rezultati na testiranju pred začetkom RKT so pokazali, da je prišlo do statistično pomembnih razlik med intervencijsko in kontrolno skupino na predtestiranju samo pri testu TMT $2(p=0,043)$. Pri ostalih testih razlike na predtestiranju niso bile statistično pomembne $(p \geq 0,123)$. 


\section{Tabela 2}

Rezultati sodelovanja $v$ intervenciji kognitivnega treninga udeležencev intervencijske skupine

\begin{tabular}{|c|c|c|c|c|}
\hline Spremenljivke & PRED & $\mathrm{PO}$ & Sprememba & $p$ za interakcijo $\left(\right.$ delni $\left.\eta^{2}\right)$ \\
\hline AVLT-U & & & & $0,039(0,139)$ \\
\hline Intervencijska & $6,13 \pm 2,00$ & $7,53 \pm 2,11^{\dagger}$ & $1,40 \pm 1,23$ & \\
\hline Kontrolna & $6,63 \pm 2,09$ & $7,15 \pm 2,14$ & $0,51 \pm 1,03$ & \\
\hline AVLT-B & & & & 0,703 \\
\hline Intervencijska & $4,56 \pm 1,86$ & $4,80 \pm 1,61$ & $0,13 \pm 1,81$ & \\
\hline Kontrolna & $3,55 \pm 2,07$ & $3,60 \pm 1,35$ & $-0,18 \pm 2,36$ & \\
\hline AVLT-OP & & & & 0,376 \\
\hline Intervencijska & $5,80 \pm 4,23$ & $6,93 \pm 4,41$ & $1,08 \pm 2,78$ & \\
\hline Kontrolna & $4,11 \pm 2,32$ & $5,75 \pm 2,83$ & $0,13 \pm 1,25$ & \\
\hline AVLT-PRE & & & & 0,845 \\
\hline Intervencijska & $10,69 \pm 2,12$ & $10,31 \pm 2,18$ & $-0,38 \pm 2,42$ & \\
\hline Kontrolna & $9,75 \pm 2,09$ & $9,87 \pm 2,56$ & $-0,17 \pm 3,19$ & \\
\hline Vflue $_{\text {fon }}$ & & & & 0,922 \\
\hline Intervencijska & $7,38 \pm 3,67$ & $7,88 \pm 3,60$ & $0,50 \pm 2,04$ & \\
\hline Kontrolna & $7,11 \pm 2,30$ & $8,27 \pm 3,00$ & $0,42 \pm 2,40$ & \\
\hline Vflue $_{\text {sem }}$ & & & & 0,653 \\
\hline Intervencijska & $16,31 \pm 4,84$ & $15,56 \pm 5,05$ & $-0,75 \pm 4,96$ & \\
\hline Kontrolna & $13,92 \pm 3,82$ & $14,53 \pm 4,90$ & $0,00 \pm 3,25$ & \\
\hline Vflue $_{\text {izm }}$ & & & & 0,860 \\
\hline Intervencijska & $8,63 \pm 3,79$ & $9,69 \pm 4,00$ & $1,06 \pm 4,46$ & \\
\hline Kontrolna & $8,08 \pm 3,55$ & $8,73 \pm 3,77$ & $0,75 \pm 4,75$ & \\
\hline TMT1* & & & & 0,133 \\
\hline Intervencijska & $83,59 \pm 27,58$ & $105,54 \pm 65,29$ & $21,95 \pm 70,65$ & \\
\hline Kontrolna & $73,29 \pm 27,63$ & $62,09 \pm 21,31$ & $-11,20 \pm 24,60$ & \\
\hline TMT2* & & & & 0,464 \\
\hline Intervencijska & $95,9 \pm 29,22$ & $110,4 \pm 68,46$ & $14,50 \pm 59,48$ & \\
\hline Kontrolna & $74,39 \pm 22,14^{\#}$ & $75,19 \pm 23,03$ & $0,81 \pm 26,16$ & \\
\hline TMT3* & & & & 0,842 \\
\hline Intervencijska & $97,17 \pm 29,27$ & $88,4 \pm 34,48$ & $-8,77 \pm 26,60$ & \\
\hline Kontrolna & $96,9 \pm 37,92$ & $91,07 \pm 30,41$ & $-5,83 \pm 47,45$ & \\
\hline TMT4* & & & & 0,890 \\
\hline Intervencijska & $205,97 \pm 73,51$ & $168,27 \pm 86,85$ & $-37,70 \pm 93,00$ & \\
\hline Kontrolna & $195,92 \pm 40,77$ & $164,54 \pm 36,95$ & $-31,38 \pm 46,08$ & \\
\hline TMT5* & & & & 0,859 \\
\hline Intervencijska & $137 \pm 111,31$ & $106,87 \pm 58,55$ & $-30,13 \pm 124,69$ & \\
\hline Kontrolna & $96 \pm 30,6$ & $72,77 \pm 27,45$ & $-23,23 \pm 27,64$ & \\
\hline $\mathrm{KSP}_{\text {nap }}$ & & & & 0,355 \\
\hline Intervencijska & $3,94 \pm 1,06$ & $4,44 \pm 1,26$ & $0,50 \pm 0,89$ & \\
\hline Kontrolna & $4,25 \pm 1,42$ & $4,33 \pm 1,05$ & $0,08 \pm 1,44$ & \\
\hline $\mathrm{DS}_{\mathrm{naz}}$ & & & & 0,166 \\
\hline Intervencijska & $2,63 \pm 0,96$ & $2,50 \pm 1,03$ & $-0,13 \pm 0,81$ & \\
\hline Kontrolna & $2,58 \pm 1,00$ & $2,93 \pm 0,80$ & $0,33 \pm 0,89$ & \\
\hline DSST & & & & 0,915 \\
\hline Intervencijska & $24,44 \pm 8,39$ & $24,94 \pm 7,02$ & $0,50 \pm 4,21$ & \\
\hline Kontrolna & $23,00 \pm 7,25$ & $24,79 \pm 7,17$ & $0,73 \pm 6,78$ & \\
\hline
\end{tabular}

Opombe: Vse vrednosti so predstavljene kot aritmetična sredina \pm standardni odklon. AVLT: Test slušno-besednega učenja (angl AuditoryVerbal Learning Test - AVLT). Vflue: Test verbalne fluentnosti. TMT: Test povezovanja (angl. Trail Making Test - TMT). KSP nap Test neposrednega pomnjenja zaporedja števil naprej, ki meri kratkoročni spomin in pozornost. DS ${ }_{\text {naz }}$ : Test neposrednega pomnjenja zaporedja števil nazaj, ki meri delovni spomin. DSST: Test kodiranja ali zamenjave števil s simboli (angl. Digit symbol substitution test - DSST). ${ }^{\dagger}$ Statistično značilno višji od vrednosti na predtestiranju pri $p<0,001 .{ }^{*}$ TMT testa niso uspešno zaključili vsi preiskovanci (TMT1: $n($ intervencijska $)=16, n($ kontrolna $)=15$; TMT2: $n($ intervencijska $)=16, n($ kontrolna $)=15$; TMT3: $n($ intervencijska $)=15$, $n($ kontrolna $)=14$; TMT4: $n($ intervencijska $)=10, n($ kontrolna $)=8$;MT5: $n($ intervencijska $)=15, n($ kontrolna $)=11)$. 


\section{Slika 3}

Povezava med skupnim številom minut RKT in najvišjim doseženim številom križišč znotraj virtualnega labirinta za vsakega posameznika intervencijske skupine

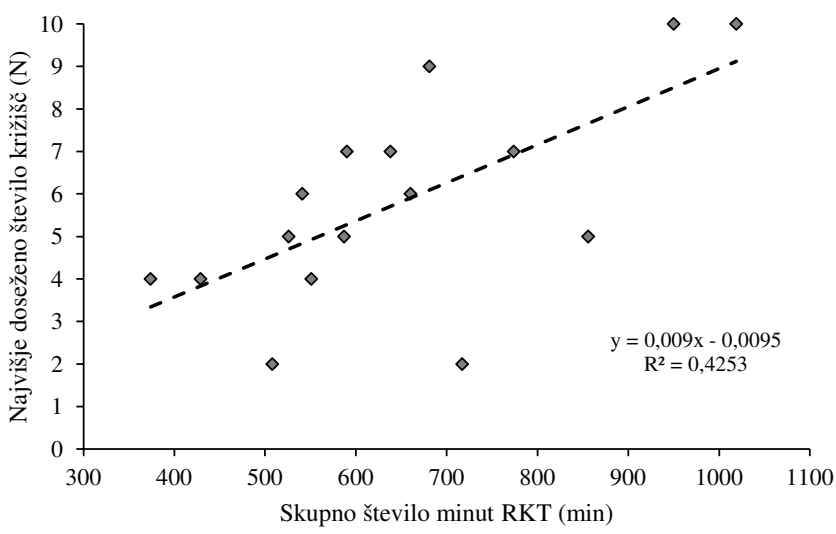

Rezultati učinkovitosti RKT so pokazali, da je do edinega statistično značilnega izboljšanja prišlo pri intervencijski skupini na testu AVLT (Tabela 2). ANOVA je pokazala statistično značilno interakcijo med časom in skupino, $F(1,29)=4,69, p=0,039, \eta^{2}=0,139$. Post hoc analiza je pokazala statistično značilno izboljšanje pri intervencijski skupini $(p<0,001)$, medtem ko izboljšanje pri kontrolni skupini ni bilo statistično značilno $(p=0,074)$ (slika 2). Pri ostalih testih ni bilo ugotovljenih pomembnih sprememb $(p \geq 0,166)$.

$\mathrm{V}$ nadaljevanju je bila ugotovljena pomembna korelacija med celotnim časom RKT in najvišjim doseženim številom križišč virtualnega labirinta $(r=0,652 ; p=0,006 ; N=16)$, kar pomeni, da so posamezniki, ki so izvajali RKT dlje časa, dosegli tudi višje zahtevnosti virtualnega labirinta (slika 3).

\section{Razprava}

Rezultati naše raziskave kažejo, da je RKT v DSO izvedljiv in tudi delno učinkovit. Učenje virtualnega labirinta po dvomesečnem RKT je izboljšalo spominske sposobnosti pri udeležencih intervencijske skupine, tj. izboljšal se je dosežek na testu AVLT-U, kjer so po intervenciji uspeli priklicati statistično značilno več besed $\mathrm{v}$ primerjavi $\mathrm{z}$ njihovim začetnim stanjem in tudi $v$ primerjavi z udeleženci kontrolne skupine, ki so kazali nespremenjeno stanje na drugem merjenju dva meseca po začetnih meritvah. Po drugi strani pa rezultati na ostalih preizkusih kognitivnih sposobnosti niso pokazali statistično značilnih sprememb. Korelacija med trajanjem RKT in dosežki na labirintu (slika 3) kaže, da dolžina trajanja RKT vpliva na doseganje višjih nivojev virtualnega labirinta.

Ugotovitve naše raziskave kažejo na a) uspešno izvedbo RKT v DSO in b) omejeno učinkovitost RKT, ki se je pokazala kot izboljšanje le na enem izmed vseh izvedenih kognitivnih testov. Udeleženci raziskave so $\mathrm{v}$ povprečju uspešno opravili 650 min RKT, kar sovpada $\mathrm{z}$ okvirno
45 minutami treninga na srečanje. Glede na subjektivne odzive udeležencev raziskave bi bilo $\mathrm{v}$ primeru zadostnih resursov bolj primerno izvesti RKT trikrat na teden s krajšim, 30-40-minutnim srečanjem. Rezultati naše metaregresijske analize (Marusic, Verghese in Mahoney, 2018) namreč kažejo, da so krajši KT ali RKT bolj učinkoviti za daljni transfer, medtem ko so ostali parametri (trajanje raziskave $\mathrm{v}$ tednih, frekvenca treninga, število tedenskih treningov, skupno število treningov in skupno število minut treninga) neznačilni.

Rezultati naše raziskave so $\mathrm{v}$ splošnem skladni z rezultati ostalih raziskav, ki so uporabljale KT (glej pregledni članek A.-K. Folkerts idr., 2017) ali RKT na udeležencih v DSO (Zhuang idr., 2013). Naše ugotovitve se skladajo z metaanalizo A.-K. Folkerts idr. (2017), ki zaključuje, da so kognitivne intervencije učinkovite tudi na populaciji $\mathrm{z}$ demenco in bi zato morale biti ponujene osebam $\mathrm{z}$ demenco tudi v DSO. Predhodna raziskava, ki je bila sicer opravljena na zdravih starejših moških, ki so bili izpostavljeni 14-dnevnemu neprekinjenemu horizontalnemu ležanju in vsakodnevnemu RKT, ni pokazala enakih rezultatov (Marusic, Giordani idr., 2018; Marusic idr., 2015, 2019). RKT je pozitivno vplival na direktno trenirane sposobnosti prostorske navigacije in pokazal izboljšanje na testu TMT-B (Marusic, Giordani idr., 2018), kar se v trenutni raziskavi ni izkazalo.

Prednosti in omejitve ter predlogi za nadaljnje raziskave

Čeprav smo izvedli to raziskavo, da bi empirično preverili izvedljivost RKT v DSO, ima raziskava prednost $\mathrm{v}$ tem, da so vsi udeleženci, tisti iz kontrolne in tisti iz intervencijske skupine, živeli v enakem okolju, tako iz dietetičnega kot iz socialnega vidika ter vidika dnevnih aktivnosti. Po našem védenju je ta raziskava prva tovrstna raziskava izvedbe RKT v DSO v Sloveniji.

Glede omejitev in predlogov za nadaljevanje tovrstnih aktivnosti v DSO je pomembno izpostaviti, da je RKT temeljil na učenju virtualnega labirinta, tj. aktivnostih, ki jih je težko prepoznati v vsakdanjem življenju v DSO. V raziskavo nismo vključili indikatorjev o vsakodnevnih aktivnostih v DSO, da bi lahko preverili, ali je RKT vplival tudi na izboljšanje dnevnih aktivnosti udeležencev (npr., orientacijo v bivalnih prostorih). Enako velja za pomanjkanje indikatorjev o življenjskem zadovoljstvu in celo daljnem transferu na posredno trenirane sposobnosti gibanja/mobilnosti (glej npr. Marusic, Giordani idr., 2018; Marusic idr., 2015).

Glede na to, da se v DSO izvajajo tudi redne gibalne in umske aktivnosti (fizio- in delovna terapija), bi bilo priporočljivo spremljati vse udeležence iz obeh skupin tudi glede njihove vključenosti $\mathrm{v}$ redne domske aktivnosti. Naš RKT ni bil integriran v dnevne aktivnosti in rutino, zato je težko preveriti morebitne interakcije med RKT in domskimi dnevnimi aktivnostmi. Lahko samo predpostavljamo, da so bile dnevne domske aktivnosti izenačene med udeleženci intervencijske in kontrolne skupine. Kot pomanjkljivost raziskave lahko omenimo rabo pasivne, ne pa tudi aktivne kontrolne skupine, kjer bi bili udeleženci kontrolne in intervencijske skupine izenačeni $\mathrm{v}$ uporabi računalnika in bi namesto treninga prostorske navigacije opravljali drugo obliko računalniškega treninga, kjer se zahtevnost nalog ne bi stopnjevala (glej npr. Verghese idr., 2016). 


\section{Zaključki}

Rezultati naše raziskave so prvi tovrstni primer izvedbe RKT v domovih starejših občanov v Sloveniji. V sklopu dvomesečnega izvajanja RKT v domovih starejših občanov smo uspešno uvedli trening ter preizkusili njegovo učinkovitost med osebami, ki nimajo ali že imajo blago kognitivno motnjo. Udeleženci intervencijske skupine so pokazali izboljšane dosežke na eni od mer preizkusa spomina, medtem ko so bile ostale testirane kognitivne sposobnosti nespremenjene. S kritičnim vpogledom v izvedbo tovrstnega RKT v domovih starejših občanov smo želeli prispevati $\mathrm{k}$ načrtovanju bodočih preventivnih ukrepov za izboljšanje ali preprečitev upada kognitivnih sposobnosti in posledično izboljšanja kvalitete življenja starejših oseb.

\section{Opombe avtorjev}

Raziskava je bila sofinancirana s strani Ministrstva za izobraževanje, znanost in šport ter Evropske unije (Evropski socialni sklad). Projekt ProTrening je preko Alme Mater Europaea - ECM prijavil dr. Uroš Marušič. $\mathrm{Za}$ pomoč pri organizaciji in izvedbi raziskave se iskreno zahvaljujemo direktoricam in zaposlenim v DEOS in DSO ter Mednarodnemu inštitutu za aplikativno gerontologijo. Za pomoč pri zbiranju podatkov se (po abecednem vrstnem redu) zahvaljujemo Mateji Antolin, Tini Černe, Ester Fabiani, Mateji Gradišek, Anji Ključevšek, Aleksandri Kuhar in Kaji Železnik.

\section{Literatura}

Bahar-Fuchs, A., Martyr, A., Goh, A. M., Sabates, J. in Clare, L. (2019). Cognitive training for people with mild to moderate dementia. Cochrane Database of Systematic Reviews.

Barry, D., Bates, M. E. in Labouvie, E. (2008). FAS and CFL forms of verbal fluency differ in difficulty: A metaanalytic study. Applied Neuropsychology, 15(2), 97-106.

Blazer, D. G., Yaffe, K. in Liverman, C. T. (2015). Cognitive aging: Progress in understanding and opportunities for action. National Academies Press.

Deary, I. J., Corley, J., Gow, A. J., Harris, S. E., Houlihan, L. M., Marioni, R. E., Penke, L., Rafnsson, S. B. in Starr, J. M. (2009). Age-associated cognitive decline. British Medical Bulletin, 92(1), 135-152.

Delis, D. C., Kramer, J. H., Kaplan, E. in Holdnack, J. (2004). Reliability and validity of the Delis-Kaplan Executive Function System: An update. Journal of the International Neuropsychological Society, 10(2), 301-303.

Folkerts, A.-K., Roheger, M., Franklin, J., Middelstädt, J. in Kalbe, E. (2017). Cognitive interventions in patients with dementia living in long-term care facilities: Systematic review and meta-analysis. Archives of Gerontology and Geriatrics, 73, 204-221.

Harvey, P. D., McGurk, S. R., Mahncke, H. in Wykes, T. (2018). Controversies in computerized cognitive training. Biological Psychiatry: Cognitive Neuroscience and Neuroimaging, 3(11), 907-915.
Imperl, F. (2012). Kakovost oskrbe starejših-izziv za prihodnost [Quality of caring for the elderly - the challenge for the future]. Firis Imperl.

Lampit, A., Hallock, H. in Valenzuela, M. (2014). Computerized cognitive training in cognitively healthy older adults: A systematic review and meta-analysis of effect modifiers. PLoS Medicine, 11(11), članek el001756.

Lindstrom, H. A., Fritsch, T., Petot, G., Smyth, K. A., Chen, C. H., Debanne, S. M., Lerner, A. L. in Friedland, R. P. (2005). The relationships between television viewing in midlife and the development of Alzheimer's disease in a case-control study. Brain and Cognition, 58(2), 157-165.

Mapelli, D., Di Rosa, E., Nocita, R. in Sava, D. (2013). Cognitive stimulation in patients with dementia: Randomized controlled trial. Dementia and Geriatric Cognitive Disorders Extra, 3(1), 263-271.

Marusic, U., Giordani, B., Moffat, S. D., Petrič, M., Dolenc, P., Pišot, R. in Kavcic, V. (2018). Computerized cognitive training during physical inactivity improves executive functioning in older adults. Aging, Neuropsychology, and Cognition, 25(1), 49-69.

Marusic, U., in Grosprêtre, S. (2018). Non-physical approaches to counteract age-related functional deterioration: Applications for rehabilitation and neural mechanisms. European Journal of Sport Science, 18(5), 639-649.

Marusic, U., Kavcic, V., Giordani, B., Gerževič, M., Meeusen, R. in Pišot, R. (2015). Computerized spatial navigation training during 14 days of bed rest in healthy older adult men: Effect on gait performance. Psychology and Aging, 30(2), 334-340.

Marusic, U., Kavcic, V., Pisot, R. in Goswami, N. (2019). The role of enhanced cognition to counteract detrimental effects of prolonged bed rest: Current evidence and perspectives. Frontiers in Physiology, 9, članek 1864.

Marusic, U., Verghese, J. in Mahoney, J. R. (2018). Cognitivebased interventions to improve mobility: A systematic review and meta-analysis. Journal of the American Medical Directors Association, 19(6), 484-491.

Mewborn, C. M., Lindbergh, C. A. in Miller, L. S. (2017). Cognitive interventions for cognitively healthy, mildly impaired, and mixed samples of older adults: A systematic review and meta-analysis of randomized-controlled trials. Neuropsychology Review, 27(4), 403-439.

Moffat, S. D., Hampson, E. in Hatzipantelis, M. (1998). Navigation in a "virtual" maze: Sex differences and correlation with psychometric measures of spatial ability in humans. Evolution and Human Behavior, 19(2), $73-87$.

Nasreddine, Z. S., Phillips, N. A., Bédirian, V., Charbonneau, S., Whitehead, V., Collin, I., Cummings, J. L. in Chertkow, H. (2005). The Montreal Cognitive Assessment, MoCA: A brief screening tool for mild cognitive impairment. Journal of the American Geriatrics Society, 53(4), 695-699.

Van Der Elst, W. I. M., van Boxtel, M. P., van Breukelen, G. J. in Jolles, J. (2005). Rey's verbal learning test: Normative data for 1855 healthy participants aged 24-81 years and the influence of age, sex, education, and mode of presentation. Journal of the International Neuropsychological Society, 11(3), 290-302. 
Verghese, J., Ayers, E., Mahoney, J. R., Ambrose, A., Wang, C. in Holtzer, R. (2016). Cognitive remediation to enhance mobility in older adults: The CREM study. Neurodegenerative Disease management, 6(6), 457-466.

Wang, J. Y. J., Zhou, D. H. D., Li, J., Zhang, M., Deng, J., Tang, M., Gao, C., Li, J., Lian, Y. in Chen, M. (2006). Leisure activity and risk of cognitive impairment: The Chongqing aging study. Neurology, 66(6), 911-913.

Wechsler, D. A. (1997). Wechsler adult intelligence scale (3rd ed.). The Psychological Corporation.

Wöhl, C., Richter, S. in Blättner, B. (2018). Cognitive interventions in nursing homes: Systematic review of the preventive effectiveness on cognitive performance in persons in need of care. Zeitschrift fur Gerontologie und Geriatrie, 51(6), 656-665.

Zakon o socialnem varstvu (ZVS- UPB2) [Social protection act]. (2007). Uradni list, RS, št. 3/2007. http://pisrs.si/Pis. web/pregledPredpisa?id=ZAKO869

Zhuang, J.-P., Fang, R., Feng, X., Xu, X.-H., Liu, L.-H., Bai, Q.-K., Tang, H.-D., Zhao, Z.-G. in Chen, S.-D. (2013). The impact of human-computer interaction-based comprehensive training on the cognitive functions of cognitive impairment elderly individuals in a nursing home. Journal of Alzheimer's Disease, 36(2), 245-251. 